\title{
Vascular endothelial growth factor mRNA and protein expression in airway epithelial cell lines in vitro
}

\author{
S. Koyama*, E. Sato", A. Tsukadaira\# ${ }^{\#}$ M. Haniuda*, H. Numanami*, M. Kurai*, S. Nagai" , T. Izumi ${ }^{\star}$
}

Vascular endothelial growth factor $m R N A$ and protein expression in airway epithelial cell lines in vitro. S. Koyama, E. Sato, A. Tsukadaira, M. Haniuda, H. Numanami, M. Kurai, S. Nagai, T. Izumi. (C) ERS Journals Ltd 2002.

ABSTRACT: Vascular endothelial growth factor (VEGF) plays multifunctional roles in vascular permeability, repair and remodelling processes, in addition to the maintenance of vascular structure and function. In the present study, the potential of airway epithelial cell lines, BEAS-2B cells and A549 cells, to release and express VEGF in unstimulated and stimulated conditions was evaluated.

The secretion and expression of VEGF were evaluated by enzyme-linked immunosorbant assay and by reverse transcriptase-polymerase chain reaction. The isoforms of released VEGF were determined by high-performance liquid chromatography.

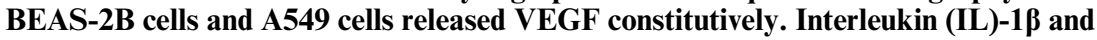
tumour necrosis factor (TNF)- $\alpha$ augmented the release of VEGF in a time- and dosedependent manner. The released VEGF was 165 amino acid residues in either condition. Pseudomonas aeruginosa lipopolysaccharide (LPS), interferon (IFN)- $\gamma$, smoke extract (SE), neutrophil elastase (NE), and bradykinin stimulated the release of VEGF. Keracinocyte growth factor (KGF), which reduces vascular permeability, also stimulated both cells to release VEGF. VEGF messenger ribonucleic acid (mRNA) was expressed both time- and dose-dependently at $2 \mathrm{~h}$, and declined after $2 \mathrm{~h}$ in response to IL-1 $\beta$ and TNF- $\alpha$. The expression of VEGF mRNA in airway epithelial cells was also augmented by LPS, IFN- $\gamma, \mathrm{SE}$, NE, and KGF stimulation.

These data suggest that airway epithelial cells may regulate the maintenance of vascular structure and function, as well as vascular permeability, repair and remodelling processes, in a variety of lung conditions by expressing vascular endothelial growth factor.

Eur Respir J 2002; 20: 1449-1456.
*The National Chuushin Matsumoto Hospital, Matsumoto, ${ }^{\#}$ The First Dept of Internal Medicine, Shinshu University School of Medicine, Matsumoto, and "Kyoto University, Dept of Respiratory Medicine, Graduate School of Medicine, Kyoto, Japan.

Correspondence: S. Koyama Pulmonary Section

The National Chuushin Matsumoto Hospital

811 Kotobuki Toyooka

Matsumoto 399-0021

Japan

Fax: 81263863190

E-mail: yskoyama@go.tvm.ne.jp

Keywords: Airway epithelial cells interleukin-1 $\beta$

tumour necrosis factor- $\alpha$

vascular endothelial growth factor

Received: October 162000

Accepted after revision: July 92002
Vascular endothelial growth factor (VEGF) is a dimorphic glycoprotein of molecular weight 34,000 $42,000 \mathrm{D}$, consisting of two disulphide-linked peptide chains with identical N-termini [1, 2]. VEGF possesses potent vascular permeability-enhancing activity. On a molar basis, it is 50,000 times more potent than histamine [1]. VEGF was first identified in tumour cell-conditioned media [3] and has been purified to homogeneity from guinea pig and human sources $[1,4]$. VEGF acts directly on cultured vascular endothelium to induce a rapid increase in free cytosolic calcium, apparently by activating a phosphoinositidespecific phospholipase- $C$ [5]. It stimulates the release of von Willebrand factor from endothelial cells [5] and induces the expression of endothelial cell tissue factor activity [6]. At the same time in other studies [7, 8], a protein selectively mitogenic for vascular endothelial cells was purified from cell culture, and this protein turned out to be the same substance that induces vascular permeability-enhancing activity. VEGF is chemotactic for endothelial cells [9] and enhances their collagenase [10] and urokinase receptor expression [11]. The existence of multiple activities embodied in the same protein suggests that VEGF may play multifunctional roles both in the development of vasculature and in the maintenance of vascular structure and function.

The gene for human VEGF is organised into eight exons. As a result of alternative splicing, at least four transcripts encoding mature VEGF have been detected, encoding VEGF containing 121, 165, 189, and 206 amino acid residues (VEGF121, VEGF165, VEGF189, and VEGF206), each preceded by a 26 amino acid signal peptide [12]. VEGF121 and VEGF165 are diffusible proteins that are secreted into medium. VEGF189 and VEGF206 have a high affinity for heparin and are mostly bound to heparin-containing proteoglycans in the extracellular matrix [13]. Transfection studies demonstrate that VEGF121 and VEGF165 are secreted and exhibit both mitogenic and peameability-inducing activities, but VEGF189 and VEGF206 remain primarily cell associated and lack the mitogenic activity of the smaller form [13, 14], suggesting that VEGF165 and VEGF121 are pivotal forms of VEGF. Among several peptide growth factors implicated in angiogenesis, including transforming growth factor (TGF)- $\beta$, platelet-derived growth factor and VEGF, only VEGF is specifically 
mitogenic for endothelial cells, having no mitogenic activity on other cell types [15]. VEGF messenger ribonucleic acid (mRNA) is found in embryonic tissues, including lung, kidney, and placenta, during organ angiogenesis [14, 16]. Although VEGF transcripts are located in epithelial cells, smooth muscle cells and macrophages in various tissues, in normal adult lung, expression is mainly in alveolar epithelial cells [17].

VEGF expression is reduced by hyperoxia, mainly in alveolar type II epithelial cells [18]. Endothelial cells proliferate during recovery from injury, but lungs have substantial morphological alterations, possibly due to the decreased expression of VEGF [18]. The decreased level of VEGF not only reduces endothelial cell growth, but also induces endothelial cell apoptosis [19], and, because of this, toxic effects on lung alveolar epithelial cells are reflected in continued abnormalities after recovery [20]. Similar mechanisms may be applied to lung injuries induced by other aetiologies, i.e. impairing lung epithelial cell functions may alter lung structure and remodelling. In contrast, hypoxia induces VEGF expression in vivo and in vitro in alveolar epithelial cells and endothelial cell proliferation [21], leading to vascular hypertrophy. Thus, it is possible that airway epithelial cells play an important role in lung repair and remodelling, by expressing VEGF. In many cases of lung injury, increased levels of pro-inflammatory cytokines and other inflammatory stimuli are reported. However, the effects of these cytokines and substances on alveolar epithelial cell VEGF expression are uncertain. In the present study, the authors evaluated whether pro-inflammatory cytokines and stimuli modulate mRNA expression and protein secretion of VEGF in airway epithelial cells, and determined the isoforms of the released VEGF.

\section{Materials and methods}

\section{Airway and alveolar epithelial cell preparation}

Obtaining primary type-II epithelial cells of sufficient purity from rat or human lungs is difficult $(>5 \%$ of alveolar macrophage contamination was not eliminated), and as such, A549 cells (passage 75; American Type Culture Collection, Rockville, MD, USA), a pulmonary type-II epithelial cell line derived from an individual with alveolar cell carcinoma, were used [22]. These cells retained many of the characteristics of normal type-II epithelial cells, such as surfactant production, cytoplasmic multilamellar inclusion bodies, and cuboidal appearance [22]. BEAS-2B cells (passage 27-29; a kind gift from C. Harris, National Institutes of Health (NIH), Bethesda, MD, USA) were used as human bronchial epithelial cells. A549 cells and BEAS-2B cells were cultured with Ham's F-12 medium supplemented with bovine foetal serum (Sigma, St. Louis, MO, USA), penicillin (50 units $\cdot \mathrm{mL}^{-1}$; GIBCO, Grand Island, NY, USA), streptomycin $\left(50 \mu \mathrm{g} \cdot \mathrm{mL}^{-1}\right.$; GIBCO $)$, and fungizone $\left(2 \mu \mathrm{g} \cdot \mathrm{mL}^{-1} ; \mathrm{GIBCO}\right)$. The cells reached confluence after 5-7 days after which they were used for experiments.

Exposure of $A 549$ and BEAS-2B cells to a variety of stimuli

A549 cells and BEAS-2B cells were exposed to interleukin (IL)-1 $\beta\left(5,50\right.$, and $500 \mathrm{pg} \cdot \mathrm{mL}^{-1}$; Genzyme, Cambridge, MA, USA) and tumour necrosis factor (TNF)- $\alpha\left(10,100\right.$, and 1,000 units $\cdot \mathrm{mL}^{-1}$; Genzyme) and incubated for $12,24,48,72$, and $96 \mathrm{~h}$. These cells were also exposed to Pseudomonas aeruginosa lipopolysaccharide (LPS, $10 \mu \mathrm{g} \cdot \mathrm{mL}^{-1}$; Sigma), interferon (IFN)- $\gamma$ (500 units $\cdot \mathrm{mL}^{-1}$; Sumitomo Pharmaceutical Co., Tokyo, Japan), smoke extract (SE, 5\%), neutrophil elastase (NE, 10 units $\cdot \mathrm{L}^{-1}$; Sigma), bradykinin (BK, $100 \mu \mathrm{M}$; Sigma), and keracinocyte growth factor (KGF, $100 \mathrm{ng} \cdot \mathrm{mL}^{-1}$; Genzyme). SE was prepared by the methods of JANOFF and CARP [23]. The concentrations of LPS, IFN- $\gamma, \mathrm{SE}, \mathrm{NE}$ and $\mathrm{BK}$ were high enough to induce the release of neutrophil and monocyte chemotactic factors from A549 cells and BEAS-2B cells [24-28]. In these stimuli, the concentration of LPS was $<10 \mathrm{ng} \cdot \mathrm{mL}^{-1}$ at the maximum stimulant concentration. Concentrations of $\mathrm{SE}$ and $\mathrm{NE}>10 \%$ and 100 units $\cdot \mathrm{L}^{-1}$, respectively, induced substantial cellular toxicity to A549 cells and BEAS$2 \mathrm{~B}$ cells, and reduced or abolished the secretion of VEGF.

Quantification of vascular endothelial growth factor proteins in A549 cell and BEAS-2B cell supernatant fluids

The concentration of VEGF in the supernatants was measured by enzyme-linked immunosorbant assay (ELISA), according to the manufacturer's instructions (VEGF kit; Amersham Pharmacia Biotech, Buckinghamshire, UK). The minimum concentration detected by this method was $15.6 \mathrm{pg} \cdot \mathrm{mL}^{-1}$. The VEGF immunoassay is designed to measure VEGF165 levels, but VEGF121 showed linear curves that were parallel to the standard curves obtained.

Determination of the isoforms of released vascular endothelial growth factor by high performance liquid chromatography

To determine the isoforms of VEGF in the supernatant fluids, high performance liquid chromatography (HPLC; Waters 2690 separations Module; Waters, MA, USA) was used. A TSK gel-G3000SW column (Tosoh Corporation, Tokyo, Japan) was used to separate VEGF isoforms containing 121, 165, 189, and 206 amino acids by molecular weight. The supernatant was filtered by Samprep LH4 (0.5 $\mu \mathrm{m}$; Millipore, MA, USA) before HPLC separation. The sample was injected into the TSK gel-G3000SW column, and the column was eluted with $0.1 \mathrm{M}$ phosphate buffer with $0.2 \mathrm{M}$ sodium chloride at $\mathrm{pH} 7.2$, at 
a flow rate of $0.5 \mathrm{~mL} \cdot \mathrm{min}^{-1}$. The VEGF protein concentration of each fraction was measured by ELISA. Chymotripsinogen $(25 \mathrm{kD}$; Serva Electrophoresis, Heidelberg, Germany) and egg albumin (45 kD, Serva Electrophoresis) were used as molecular markers. The human recombinant VEGF165 was also eluted under the same conditions, and the VEGF concentration of each fraction was measured to assess the fraction profile of VEGF165.

\section{Evaluation of vascular endothelial growth factor messenger ribonucleic acid expression}

Reverse transcriptase-polymerase chain reaction (PCR) was used to evaluate VEGF mRNA expression in both cells after $30,60,90,120,150,240$ and 360min incubations with $500 \mathrm{pg} \cdot \mathrm{mL}^{-1}$ of IL-1 $\beta$. The dose response expression of VEGF to IL-1 $\beta$ was examined at concentrations of 5,50 , and $500 \mathrm{pg} \cdot \mathrm{mL}^{-1}$ of IL- $1 \beta$ and 10,100 , and 1,000 units $\cdot \mathrm{mL}^{-1}$ of TNF- $\alpha$. Total RNA was extracted from A549 and BEAS-2B cells as described previously [29]. Total RNA $(1 \mu \mathrm{g})$ was reverse transcribed into complementary deoxyribonucleic acid (cDNA) with a cDNA synthesis kit (Boehringer Mannheim GmbH, Mannheim, Germany), and then amplified for 17 cycles in PERKIN ELMER Gene Amp PCR System 9600 (Perkin Elmer, Norwalk, CT, USA) desaturation at $94^{\circ} \mathrm{C}$ for $30 \mathrm{~s}$, primer annealing at $55^{\circ} \mathrm{C}$ for $30 \mathrm{~s}$, and primer extension at $72^{\circ} \mathrm{C}$ for $30 \mathrm{~s}$. VEGF and $\beta$-actin sense, antisense, and probe used in the present study were as follows: VEGF (sense: 5-GCT CTA CCT CCA CCA TGC CA-3'; antisense: 5'-AGC TCA TCT CTC CTA TGT GC-3'; probe: 5'-ATG GAT GTC TAT CAG CGC AGC TAC T- $3^{\prime}$ ) and $\beta$-actin (sense: $5^{\prime}$-CTT CTA CAA TGA GCT GCG TG - $3^{\prime}$; antisense: 5'-TCA TGA GGT AGT CAG TCA GG-3'; probe: human cDNA probe).

Preliminary studies indicated that $>27$ cycles were subsaturating for mRNA tested, and thus were appropriate for comparison of relative levels of mRNA between groups. PCR products were separated by electrophoresis on 3\% agarose gel and visualised by autoradiography. PCR band densities were determined by an NIH image analytical program on unaltered, computer-scanned images. $\beta$-actin mRNA, which has been shown not to change by stimulation, was measured in both normal and stimulated RNA samples at each point, using the same cDNA that was analysed for cytokines. Integrated optical density (IOD) measurement of 10 separate $\beta$-actin samples did not vary $>10 \%$ from the mean IOD, which is an indication of expected variation resulting from experimental technique.

\section{Statistics}

In experiments where multiple measurements were made, differences between groups were tested for significance using one-way analysis of variance with Duncan's multiple range test applied to data at specific time and dose points. In experiments where single measurements were made, the differences between groups were tested for significance using Student's unpaired t-tests. In all cases, $\mathrm{p}<0.05$ was considered significant.

\section{Results}

Dose- and time-related release of VEGF protein from A549 and BEAS-2B cells in response to $I L-1 \beta$ and $T N F-\alpha$

IL-1 $\beta$ and TNF- $\alpha$ stimulated the release of VEGF in a time- and dose-dependent manner (figs. 1 and 2). Both A549 and BEAS-2B cells released VEGF protein constitutively. The augmented release of VEGF protein was observed after 48-h incubation in response to $500 \mathrm{pg} \cdot \mathrm{mL}^{-1}$ of IL-1 $\beta$ or after $72 \mathrm{~h}$ in response to 1,000 units $\cdot \mathrm{mL}^{-1}$ of TNF- $\alpha$ in A549 cells. BEAS-2B cells released VEGF protein after $48 \mathrm{~h}$ in response to IL-1 $\beta$ and TNF- $\alpha$. After $72-h$ incubation, IL-1 $\beta$ and TNF- $\alpha$ induced the release of significant VEGF protein concentrations from A549 and BEAS-2B cells, of $50 \mathrm{pg} \cdot \mathrm{mL}^{-1}$ and 100 units $\cdot \mathrm{mL}^{-1}$, respectively.

Release of vascular endothelial growth factor from A549 cells and BEAS-2B cells in response to a variety of stimuli

LPS, IFN- $\gamma, \mathrm{SE}, \mathrm{BK}$, and NE significantly stimulated both cell types to release VEGF protein. KGF augmented the secretion of VEGF from both types of cells (table 1).

Release of vascular endothelial growth factor 165 from airway epithelial cells

The measurement of every fraction of the supernatant fluid separated by HPLC showed that only VEGF165 was detectable at the fraction number of $36-40$ in the unstimulated and IL-1 $\beta$-stimulated A549 cell supernatant fluids. These fractions coincided exactly with the fraction number in which human recombinant VEGF165 was eluted. The fraction numbers of chymotrypsinogen $(25 \mathrm{kD})$ and egg albumin $(44 \mathrm{kD})$ were 50 and 34 , respectively. In contrast, VEGF121, VEGF189, and VEGF206 were not detected in any fractions. Therefore, airway epithelial cells predominantly secreted VEGF165 rather than other forms of VEGF in both stimulated and unstimulated conditions.

Vascular endothelial growth factor $m R N A$ expression in response to $I L-1 \beta$ in a time- and dose-dependent manner

IL-1 $\beta$ augmented the expression of VEGF mRNA in a time-dependent manner in A549 and BEAS-2B 

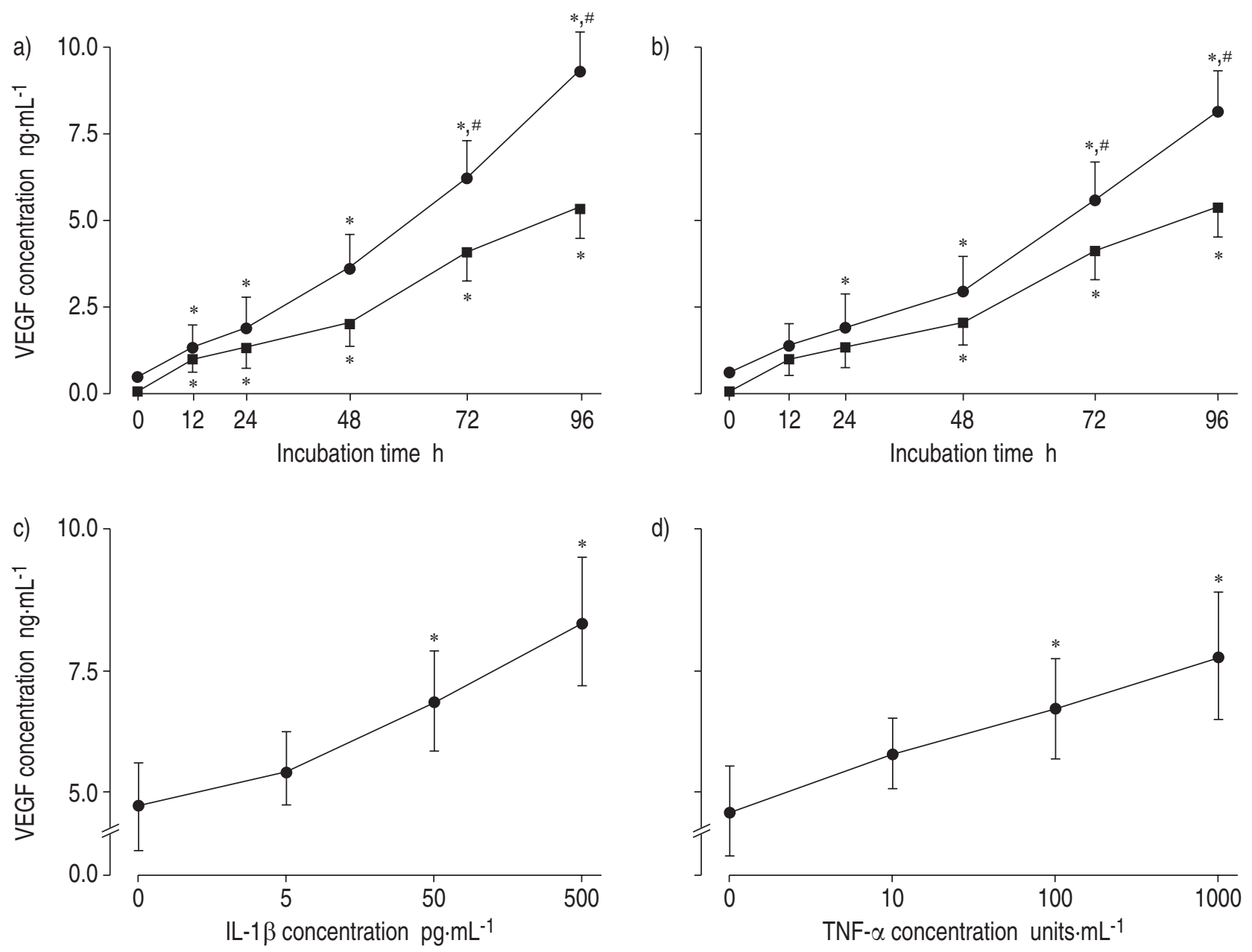

Fig. 1. - Release of vascular endothelial growth factor (VEGF) in response to interleukin (IL)-1 $\beta$ and tumour necrosis factor (TNF)- $\alpha$ in a dose- and time-dependent manner from A549 cell monolayers $(n=6)$. The mean \pm SEM release of VEGF can be seen in a time-dependent manner in response to a) $500 \mathrm{pg} \cdot \mathrm{mL}^{-1}$ of IL-1 $\beta$ and b) 1,000 units $\cdot \mathrm{mL}^{-1}$ of TNF- $\alpha$. Closed squares express unstimulated supernatant fluids and closed circles express IL-1 $\beta$ or TNF- $\alpha$-treated supernatant fluids. The mean \pm SEM release of VEGF can be seen in a dose-dependent manner in response to c) IL-1 $\beta$ and d) TNF- $\alpha$ after 72-h incubation. *: p $<0.05$ compared with the unstimulated supernatant fluids; \#: $\mathrm{p}<0.05$ compared with constitutive release of VEGF from A549 cells.

cells (fig. 3). The maximum expression of VEGF was as early as $60 \mathrm{~min}$, and then the expression declined in response to IL-1 $\beta$ in both types of cells. The upregulation of VEGF mRNA expression was not observed after 12-24-h exposure (data not shown). VEGF mRNA was slightly expressed constitutively in A549 and BEAS-2B cells (fig. 4). IL-1 $\beta$ augmented the expression of VEGF mRNA in a dose-dependent manner as well as the secretion of VEGF protein in both cell types (fig. 4).

Vascular endothelial growth factor $m R N A$ expression in response to a variety of stimuli

Although A549 and BEAS-2B cells expressed VEGF mRNA constitutively, LPS, IFN- $\gamma$, SE, NE, and KGF further stimulated BEAS-2B and A549 cells to express VEGF mRNA after 60-min exposure at the same concentrations that induced the release of VEGF protein (fig. 5).

\section{Discussion}

These results demonstrate that VEGF mRNA and protein are expressed constitutively in airway epithelial cells in vitro. As determined by Northern blotting on a per actin basis, the relative abundance of VEGF mRNA in adult tissue is lung > kidney> liver $>$ brain $>$ spleen in human, guinea pig, mouse, and rat tissues [17, 30, 31], suggesting that the function of VEGF in the lung tissue may be critical to normal physiology, and thus expression is highly conserved. In humans, guinea pigs, mice, and rats [17, 30, 31], cellular localisation in the lung was observed primarily in the alveolar epithelial cells, suggesting a possible role for VEGF in the maintenance of the unique balance of microvascular permeability in the lung. The reports that there was no apparent expression in endothelial cells strongly suggest that VEGF acts as a paracrine but not an autocrine factor in the lung.

Pulmonary capillaries are approximately two-fold more permeable to proteins than most peripheral 

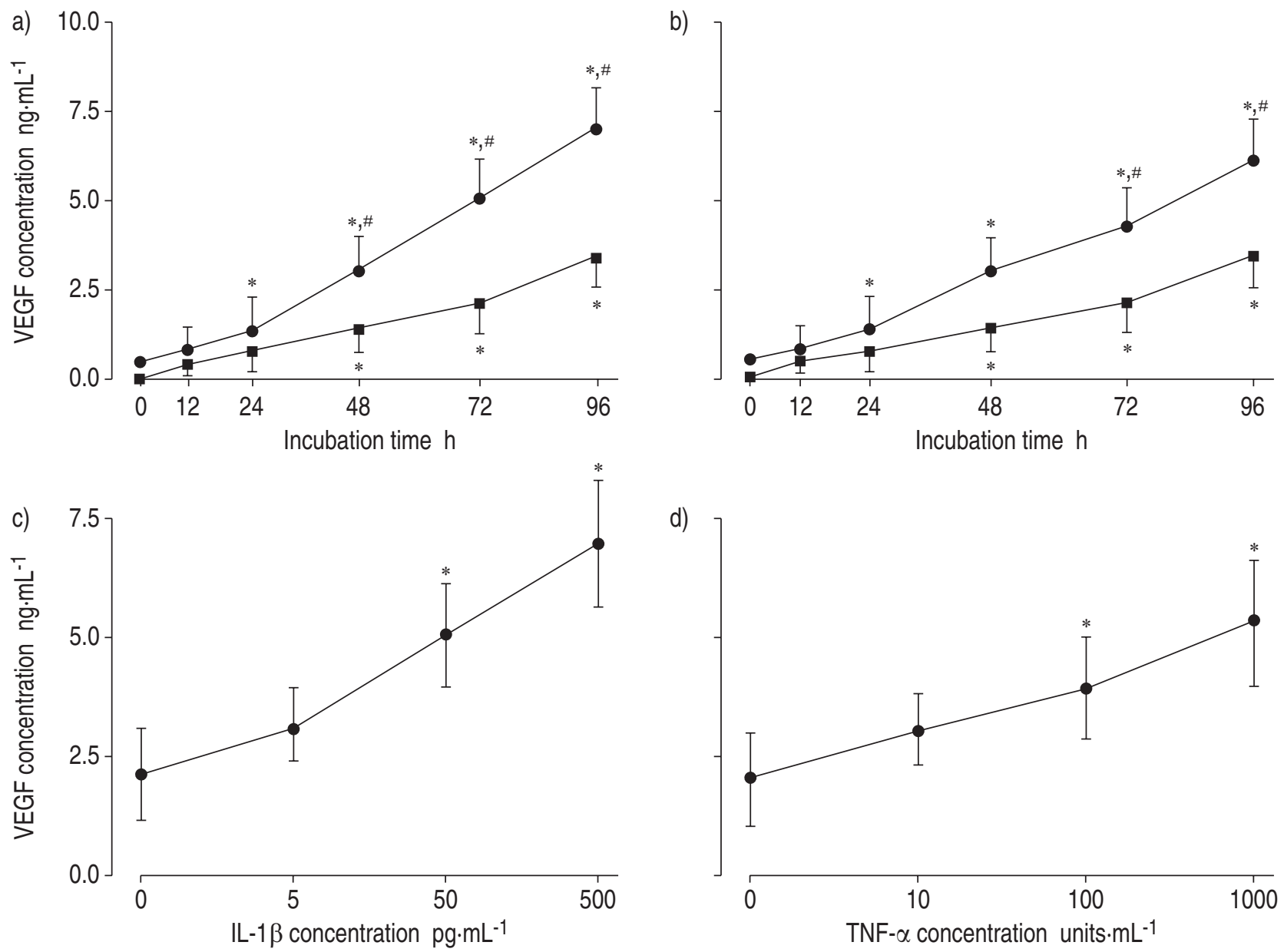

Fig. 2. - Release of vascular endothelial growth factor (VEGF) in response to interleukin (IL)-1 $\beta$ and tumour necrosis factor (TNF)- $\alpha$ in a dose- and time-dependent fashion from BEAS-2B cell monolayers $(n=6)$. The mean \pm SEM release of VEGF can be seen in a timedependent manner in response to a) $500 \mathrm{pg} \cdot \mathrm{mL}^{-1}$ of IL-1 $\beta$ and b) 1,000 units $\cdot \mathrm{mL}^{-1}$ of TNF- $\alpha$. Closed squares express unstimulated supernatant fluids and closed circles express IL-1 $\beta$ or TNF- $\alpha$-treated supernatant fluids. The mean \pm SEM release of VEGF can be seen in a dose-dependent manner in response to c) IL- $1 \beta$ and d) TNF- $\beta$ after 72 -h incubation. *: $p<0.05$ compared with the unstimulated supernatant fluids; ${ }^{\#}: \mathrm{p}<0.05$ compared with constitutive release of VEGF from BEAS-2B cells.

capillaries [32]. The expression of VEGF mRNA in steady state and by stimuli in airway epithelial cells suggests that this factor may be involved in the

Table 1. - The release of vascular endothelial growth factor (VEGF) in response to a variety of stimuli from A549 cell $(n=6)$ and BEAS-2B cell $(n=6)$ monolayers after 72-h incubation

A549 cells BEAS-2B cells

\begin{tabular}{lll}
\hline Control & $3997 \pm 123$ & $2527 \pm 115$ \\
Lipopolysaccharide & $6549 \pm 418^{* * *}$ & $3650 \pm 168^{* *}$ \\
$\quad 10 \mu \mathrm{g} \cdot \mathrm{mL}^{-1}$ & & \\
IFN- $\gamma 500$ units $\cdot \mathrm{mL}^{-1}$ & $5980 \pm 589^{* *}$ & $3970 \pm 249^{* *}$ \\
SE $5 \%$ & $8890 \pm 367^{* * *}$ & $3790 \pm 323^{* *}$ \\
Bradykinin $100 \mu \mathrm{M}$ & $4710 \pm 341^{* *}$ & $3910 \pm 231^{* *}$ \\
NE 10 units. $\mathrm{L}^{-1}$ & $4290 \pm 244^{* *}$ & $3344 \pm 238^{* *}$ \\
KGF $100 \mu \mathrm{g} \cdot \mathrm{mL}^{-1}$ & $5860 \pm 348^{* *}$ & $5880 \pm 348^{* *}$ \\
\hline
\end{tabular}

Values are presented as mean $\pm \mathrm{SEM} \mathrm{pg} \cdot \mathrm{mL}^{-1}$. IFN- $\gamma$ : interferon$\gamma$; SE: smoke extract; NE: neutrophil elastase; KGF: keracinocyte growth factor. ${ }^{* *}: \mathrm{p}<0.01$ compared with control; $* * *: \mathrm{p}<0.001$ compared with control. a)

VEGF $320 \mathrm{bp}$

$\beta$-actin 305 bp
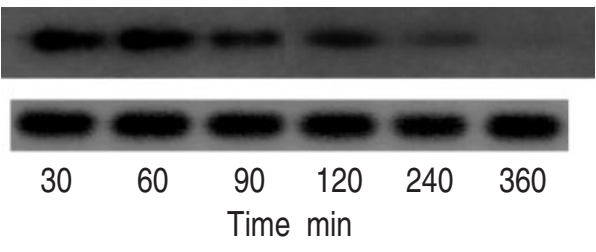

b)

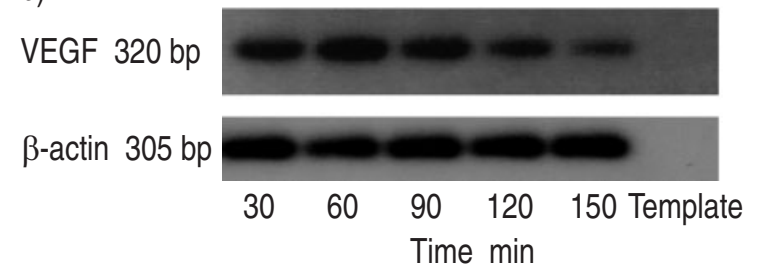

Fig. 3. - The time-dependent expression of vascular endothelial growth factor (VEGF) messenger ribonucleic acid from a) A549 cell monolayer and b) BEAS-2B cell monolayer in response to interleukin (IL)-1 $\beta$. A549 cells were stimulated by $500 \mathrm{pg} \cdot \mathrm{mL}^{-1}$ of $\mathrm{IL}-1 \beta$ for $30,60,90,120,150,240$, and $360 \mathrm{~min}$. The data presented is representative of three experiments. bp: base pairs. 
a)

VEGF $320 \mathrm{bp}$

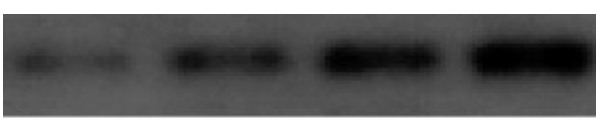

$\beta$-actin 305 bp

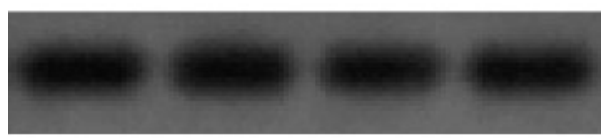

b)

VEGF $320 \mathrm{bp}$

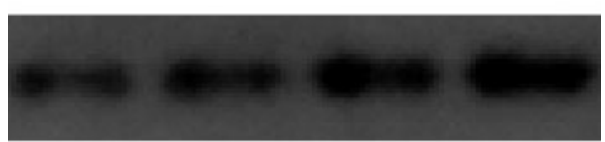

$\beta$-actin $305 \mathrm{bp}$

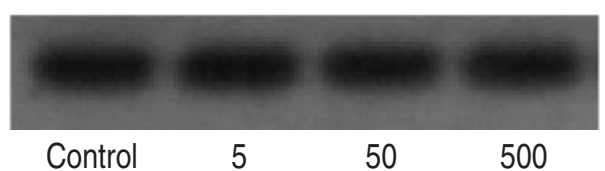

IL-1 $\beta \mathrm{pg} \cdot \mathrm{mL}^{-1}$

Fig. 4. - The dose-dependent expression of vascular endothelial growth factor (VEGF) messenger ribonucleic acid from a) A549 cell monolayer and b) BEAS-2B cell monolayer in response to interleukin (IL)- $1 \beta$. Cells were stimulated by 5,50 , and $500 \mathrm{pg} \cdot \mathrm{mL}^{-1}$ of IL-1 $\beta$ for $60 \mathrm{~min}$. The data presented is representative of three experiments. bp: base pairs.

regulation of capillary function and permeabilityenhancing effects of the lung. However, the finding that expression of VEGF mRNA occurs diffusely in the brain and is concentrated in the cerebellar granule cell layer suggests that neither the angiogenesis nor the permeability-inducing activity of VEGF is of primary importance in the brain. VEGF has been reported to stimulate hexose transport in isolated peripheral endothelial cells [33]. Similarly, airway epithelial cells may regulate the transport of small molecules (e.g. glucose and amino acids) to support the increased requirement for energy of epithelial cells themselves.

The increased expression of VEGF mRNA and

a)

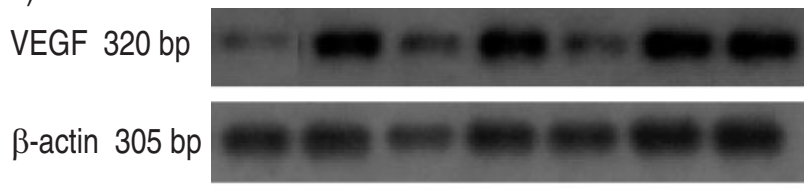

b)

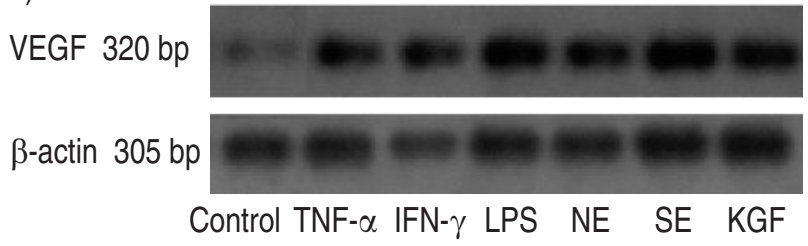

Fig. 5.-Tumour necrosis factor (TNF)- $\alpha$, interferon (IFN)- $\gamma$, lipopolysaccharide (LPS), neutrophil elastase (NE), smoke extract (SE), and keratinocyte growth factor (KGF) stimulated a) A549 cell and b) BEAS-2B cell monolayers to express vascular endothelial growth factor (VEGF) messenger ribonucleic acid after 60 -min incubation at the same concentrations used to induce VEGF secretion. The data presented is representative of three experiments. bp: base pairs. protein in airway epithelial cells by IL- $1 \beta$, TNF- $\alpha$, LPS, BK and KGF suggests a contribution to pathological states characterised by increased permeability, such as pulmonary oedema associated with adult respiratory distress syndrome. Moreover, the concomitant release of neutrophil and monocyte chemotactic activity i.e. IL-8, granulocyte-colony stimulating factor, monocyte chemotactic peptide-1, and granulocyte-macrophage colony-stimulating factor, from airway epithelial cells in response to IL-1 $\beta$, TNF- $\alpha$, LPS, SE and BK, was reported [24-28]. Thus, airway epithelial cells may regulate the permeability of lung blood vessels in the inflammatory lung diseases in combination with inflammatory cell recruitment.

A more complete understanding of the functions of VEGF in the lung depends on several factors, the size and bioactivity of VEGF expressed, the presence of VEGF receptors on adjacent endothelial cells, and the knowledge of mechanisms of both mitogenic and permeability responses. Among them, the size of VEGF secreted is of importance. Although direct analysis of which VEGF forms are expressed has not been systematically performed in all of the tissues and species in which VEGF has been identified, in human tissues, VEGF165 seems to be the predominant form, followed by VEGF121 and VEGF189 [34, 35]. The physiological significance of multiple forms of VEGF has not been established. Transfection studies demonstrated that VEGF165 and VEGF121 are secreted and exhibit both mitogenic and permeability-inducing activities, whereas VEGF206 and VEGF189 remain primarily cell-associated and lack the mitogenic activity of the smaller forms $[13,14]$. In the present study, the secreted form of VEGF was predominantly VEGF165 and other forms of VEGF were not secreted from airway epithelial cells. VEGF165 is bioactive and may diffuse to the receptors of endothelial cells, such that airway epithelial cells may regulate many endothelial cell functions by releasing VEGF.

The concentration of LPS required to stimulate A549 and BEAS-2B cells was greater than that required for monocyte/macrophage stimulation. Although the actual concentration of LPS at the site of bacterial infection or colonisation is uncertain, the LPS concentration in bronchoalveolar lavage fluids in patients with adult respiratory distress syndrome was $1-1,585 \mathrm{pg} \cdot \mathrm{mL}^{-1}$ [4]. Bronchoalveolar lavage fluid was diluted $50-100$ times, indicating that the local concentration of LPS at the site of bacterial infection or colonisation would be far higher than that generally found in the epithelial lining fluid. Thus, the concentration of $10 \mu \mathrm{g} \cdot \mathrm{mL}^{-1}$ of LPS may be accessible at the site of the infection or colonisation.

In the present study, there was an apparent discrepancy between the delay of the VEGF protein release and a rapid and transient expression of VEGF mRNA. Although the VEGF mRNA expression was slightly augmented after 12-24 h exposure, the first increase in VEGF protein was observed after $24 \mathrm{~h}$. The cell number in the dish exposed to the stimuli for $72 \mathrm{~h}$ did not significantly increase compared with the unexposed dish. Furthermore, the cell number did not change after 72-h incubation compared with the initial number. Thus, it is unlikely that the increase in 
the cell number explains the constitutive increase in the release of VEGF and the discrepancy of the data. An alternative explanation may be due to the generation of a second stimulus that induces VEGF from airway epithelial cells.

In the present study, transfected bronchial epithelial cells and an adenocarcinoma cell line were used as model type-II alveolar epithelial cells. However, Boussat et al. [36] reported that primary human bronchial epithelial cells expressed VEGF and that the expression was upregulated by hypoxia and TGF- $\beta 1$ treatment, as well as transformed human epithelial cells lines, including A549 cells [36]. The released VEGF from primary human bronchial epithelial cells was VEDF165 and had mitogenic activity of endothelial cells. Thus, human bronchial epithelial cells may have the potential to produce VEGF165 as well as transfected and transformed airway epithelial cells.

In conclusion, airway epithelial cells express vascular endothelial growth factor 165 constitutively and in response to a variety of stimuli. The secreted form of vascular endothelial growth factor was vascular endothelial growth factor 165 , suggesting that the released vascular endothelial growth factor was functionally competent on endothelial cells. Although the exact function of vascular endothelial growth factor in the lung needs further study, airway epithelial cells may regulate many endothelial cell functions by releasing vascular endothelial growth factor.

\section{References}

1. Senger DR, Connolly DT, van De Water L, Feder J, Dvorak HF. Purification and NH2-terminal amino acid sequence of guinea pig tumor-secreted vascular permeability factor. Cancer Res 1990; 50: 1774-1778.

2. Yeo T-K, Senger DR, Dvorak HF, Freter L, Yeo $\mathrm{K}-\mathrm{T}$. Glycosylation is essential for efficient secretion but not for permeability-enhancing activity of vascular permeability factor (vascular endothelial growth factor). Biochem Biophys Res Comm 1991; 179: 1568 1575 .

3. Senger DR, Galli SJ, Dvorak AM, Perruzzi CA, Harvey VS, Dvorak HF. Tumor cells secrete a vascular permeability factor that promotes accumulation of ascites fluid. Science 1983; 219: 983-985.

4. Connolly DT, Olander JV, Heuvelman D, et al. Human vascular permeability factor. Isolation from U937 cells. J Biol Chem 1989; 264: 20017-20024.

5. Brock TA, Dvorak HF, Senger DR. Tumor-secreted vascular permeability factor increases cytosolic $\mathrm{Ca} 2+$ and von Willebrand factor release in human endothelial cells. Am J Pathol 1991; 138: 213-221.

6. Clauss M, Gerlach M, Gerlach $\mathrm{H}$, et al. Vascular permeability factor: A tumor-derived polypeptide that induces endothelial cell and monocyte procoagulant activity, and promote monocyte migration. J Exp Med 1990; 172: 1535-1545.

7. Leung DW, Cachianes G, Kuang W-J, Goeddel DV, Ferrara N. Vascular endothelial growth factor is a secreted angiogenic mitogen. Science 1989; 246: 13061309.

8. Conn G, Bayne ML, Soderman DD, et al. Amino acid and cDNA sequence of a vascular endothelial cell mitogen that is homologous to platelet-derived growth factor. Proc Natl Acad Sci USA 1990; 87: 2628-2632.

9. Koch AH, Harlow LA, Haines GK, et al. Vascular endothelial growth factor. A cytokine modulating endothelial function in rheumatoid arthritis. J Immunol 1994; 152: 4149-4156.

10. Unemori EN, Ferrara N, Bauer EA, Amento EP. Vascular endothelial growth factor induces interstitial collagenase expression in human endothelial cells. $J$ Cell Physiol 1992; 153: 557-562.

11. Mandriota SJ, Segherri G, Vassali JD, et al. Vascular endothelial growth factor increases urokinase receptor expression in vascular endothelial cells. $J$ Biol Chem 1995; 270: 9709-9716.

12. Tischer E, Mitche R, Hartman T, et al. The human gene for vascular endothelial growth factor. Multiple protein forms are encoded through alternative splicing. J Biol Chem 1991; 266: 11947-11954.

13. Houkt KA, Ferrara N, Winer J, Cachianes G, Li B, Leung DW. The vascular endothelial growth factor family: identification of a fourth molecular species and characterization of alternative splicing of RNA. $\mathrm{Mol}$ Endocrinol 1991; 5: 1806-1814.

14. Breier G, Albrecht U, Sterrer S, Risau W. Expression of vascular endothelial growth factor during embryonic angiogenesis and endothelial cell differentiation. Development 1992; 114: 521-532.

15. Thomas KA. Vascular endothelial growth factor, a potent and selective angiogenic agent. $J$ Biol Chem 1996; 271: 603-606.

16. Shifren JL, Doldi N, Ferrara N, Mesiano S, Jeffe RB. In the human fetus, vascular endothelial growth factor is expressed in epithelial cells and myocytes, but not vascular endothelium - implication for mode of action. J Clin Endocrinol Metab 1994; 79: 316-322.

17. Monacci WT, Merrill MJ, Oldfield EH. Expression of vascular permeability factor/endothelial growth factor in normal rat tissue. Am J Physiol 1993; 264: C995C1002.

18. Maniscalco WM, Watkins RH, D'Angio CT, Ryan RM. Hyperoxic injury decreases alveolar epithelial cell expression of vascular endothelial growth factor (VEGF) in neonatal rabbit lung. Am $J$ Respir Cell Mol Biol 1997; 16: 557-567.

19. Shaheen RM, Davis DW, Liu W, et al. Antiangiogenic therapy targeting the tyrosine kinase inhibitor for vascular endothelial growth factor receptor inhibits the growth of colon cancer liver metastasis and induces tumor and endothelial cell apoptosis. Cancer Res 1999; 59: 5412-5416.

20. Randell SH, Mercer RR, Young SL. Neonatal hyperoxia alters the pulmonary alveolar and capillary structure of 40-day-old rat. Am J Pathol 1990; 136: $1259-1266$.

21. Shweiki D, Itin A, Soffer D, Keshet E. Vascular endothelial growth factor induced by hypoxia may mediate hypoxia-initiated angiogenesis. Nature 1992; 359: 843-845.

22. Leiber M, Smith B, Szakal A, Nelson-Rees W, Todaro G. A continuous tumor-cell line from a human lung carcinoma with properties of type II alveolar epithelial cells. Int J Cancer 1976; 17: 62-70.

23. Janoff A, Carp H. Possible mechanisms of emphysema in smokers: cigarette smoke condensate suppresses protease inhibition in vitro. Am Rev Respir Dis 1977; 116: 65-72.

24. Koyama S, Sato E, Nomura H, et al. Alveolar type 
II-like cells release G-CSF as neutrophil chemotactic activity. Am J Physiol 1998; 275: L687-L693.

25. Koyama S, Sato E, Nomura H, Kubo K, Nagai S, Izumi T. Bradykinin stimulates A549 cells to release neutrophil and monocyte chemotactic activity. Am J Pathol 1998; 153: 1885-1893.

26. Masubuchi T, Koyama S, Sato E, et al. Smoke extract stimulates alveolar type II cells to release neutrophil and monocyte chemotactic activity. Am J Pathol 1998; 153: 1903-1912.

27. Koyama S, Sato E, Nomura H, et al. IL-1 and TNFalpha stimulate A549 cells to release monocyte chemotactic activity. Eur Respir J 1999; 13: 820-828.

28. Koyama S, Sato E, Nomura H, et al. The potential of various lipopolysaccharides to release monocyte chemotactic activity from lung epithelial cells and fibroblasts. Eur Respir J 1999; 14: 545-552.

29. Chomczynski P, Sacchi N. Single-step method of RNA isolation by acid guanidium-thiocyanatephenol-chloroform extraction. Anal Biochem 1986; 162: 156-159.

30. Berse B, Brown LF, van De Water L, Dvorak HF, Senger DR. Vascular permeability factor (vascular endothelial growth factor) gene is expressed differently in normal tissues, macrophages, and tumors. Mol Biol Cell 1993; 3: 211-220.
31. Clarffey KP, Wilkinson WO, Spiegelman BM. Vascular endothelial growth factor: regulation by cell differentiation and activated second messenger pathways. J Biol Chem 1992; 267: 16317-16322.

32. Guyton AC. Textbook of Medical Physiology. 8th edn. Philadelphia, Saunders, 1991.

33. Pekala P, Marlow M, Heuvelman D, Connolly D. Regulation of hexose transport in aortic endothelial cells by vascular permeability factor and tumor necrosis factor- $\alpha$, but not by insulin. $J$ Biol Chem 1990; 265: 18051-18054.

34. Berkman RA, Merrill MJ, Reinhold WC, et al. Expression of the vascular permeability growth factor/vascular endothelial growth factor gene in central nervous system neoplasmas. $J$ Clin Invest 1993; 91: 153-159.

35. Martin TR, Rubenfeld GD, Ruzinski JT, et al. Relationship between soluble CD14, lipopolysaccharide-binding protein, and the alveolar inflammatory response in patients with adult respiratory distress syndrome. Am J Respir Crit Care Med 1997; 155: $937-$ 944.

36. Boussat S, Eddahibi S, Coate A, et al. Expression of vascular endothelial growth factor in human pulmonary epithelial cells. Am J Physiol 2000; 279: L371L378. 